\title{
Whose Life Should Be Reformed?: The Transformation of the Life Reform Movement in Prewar Japan
}

\author{
Eisuke Hisai ${ }^{1}$ \\ ${ }^{1}$ Associate Professor, Graduate School of Education, Hiroshima University, Japan \\ Correspondence: Eisuke Hisai, Graduate School of Education, Hiroshima University, Japan. Tel: \\ 81-82-424-6746, E-mail: hisai@hiroshima-u.ac.jp
}

Received: February 21, 2018

Accepted: March 23, 2018

Online Published: April 4, 2018

doi:10.5539/ach.v10n2p10

URL: http://dx.doi.org/10.5539/ach.v10n2p10

\begin{abstract}
This paper aims to show that the life reform movement taking place in Japanese cities before the Second World War was not separate from the postwar life reform movement taking place in rural areas; rather, it possessed aspects that were continued after the war. Previous studies have pointed out that life reform movement organizations established in cities in the Taisho period targeted the middle class. However, they have only made fragmentary references to the fact that such organizations instead came to emphasize the importance of farmers, who made up the majority of the population, starting in the late 1920s. This paper is a case study of the activities of the Life Reform League (renamed the Central Association of Life Reform in November 1933), which spearheaded prewar Japan's life reform movement. The results of this study clarify that the leaders of the life reform movement in the late 1920s and beyond focused on farmers, who made up the majority of the population, as a new target demographic to stop the movement from stagnating. Moreover, they proposed a movement with a foundation consisting not of individuals, but of small, community-based groups. Although many of the organization's new initiatives never left the planning stages, this change in the organization's activity policy is nonetheless a clear indication of the process by which the initial principle of "life reform," concerned with only part of society, transitioned to become a postwar principle concerned with the entire Japanese population.
\end{abstract}

Keywords: Life reform movement, middle class, social education, farmers

\section{Introduction}

\subsection{Overview of the Life Reform Movement in Modern Japan}

The Japanese life reform movement (生活改善運動, Seikatsu kaizen undō) consisted of social education (Note 1) activities aimed at encouraging people to economize and pursue scientific rationalization in everyday customs and behaviors related to daily necessities and social life. This movement flourished in the cities from the late 1910 s through the 1920s. The initiative eventually came to be promoted not only by private organizations but also by government organizations, leading to the holding of exhibitions, seminars, and lecture meetings as well as the creation and distribution of lists enumerating the objectives of life reform. In addition to this, educational activities were conducted in a variety of forms, such as magazine publications, public acknowledgement projects, the lending of reference materials, and radio broadcasts.

The principal origin of the Japanese life reform movement was a movement advocating a "simple life" in the first half of the 1900s. During this period, newspapers, books, magazines, and other media were used to inform the middle class of the importance of pursuing a simple life by rejecting ostentation and extravagance. Representative of this was the information campaign of Toshihiko Sakai (堺利彦) (publication of Katei Zasshi [家庭雑誌, Household Journal]), who later became a celebrated socialist. Subsequently, the simple life advocacy become more concrete from the standpoint of home lifestyle with the initiatives of Motoko Hani (羽仁 もと子) (publication of the magazine Shufu no Tomo [主婦之友, Housewives' Companion]) in the 1900s and the 1910s. In addition to this, the advocacy of the simple life was greatly influenced by the Taylorism-inspired scientific perspective with the initiatives of Shinsuke Hashiguchi (橋口信助) and Suzuko Misumi (三角錫子), who worked with Jūtaku Kairyōkai (住宅改良会, The Housing Reform Association) in that same period. However, as these initiatives unfolded, in the end it was not the idea of the simple life that spread but "life reform," which also signified a qualitative improvement in the quality of life. From the late 1910s to the first half of the 1920s, a host of organizations with the aim of reforming all aspects of life were established, especially in 
cities. These organizations were both private and public, as some were established through the investment and involvement of central government organizations. Despite their initial success, most of these organizations and the urban life reform movement itself began stagnating by the second half of the 1920s.

\section{Material Studied}

\subsection{The Life Reform Movement in the Taisho and Early Showa Periods}

Researchers from a variety of fields and perspectives, including the history of social education, women's history, economic history, have sought to understand the life reform movement in Japan during the prewar period, especially during the Taisho and early Showa periods. Based on the results of such studies, international researchers of Japanese history have debated the outline and features of the life reform movement during the prewar period (Garon, 1994, pp. 356-357; Sand, 2003, pp. 162-202).

From the second half of the 1960s to the 1970s, studies overviewed of the life reform movement before the Second World War and suggested that it was part of the policy for ideological indoctrination (Miyasaka, 1966; Nakajima, 1974). Building on this, studies in the 1980s began dealing more fully with the character of the contemporary life reform movement. Research in the 1980s and beyond has pointed out that the life reform movement was not simply a moral and one-sided ideological indoctrination, but consisted of initiatives that emphasized "rationalization" and "scientification," as well as somewhat affirmed people's desire for an improved quality of life (Kobayashi, 1984; Koyama, 1999; Hirade, 2006).

As mentioned above, the life reform movement in prewar Japanese cities was stagnating by the second half of the 1920s. Previous studies have identified a variety of causes for this. Kōsaku Miyasaka writes that the causes of the movement's stagnation in the early Showa period were factors such as how the promoted activities could be reduced to the "budget management" of individuals and how the initiatives were advanced half-privately and half-publicly (Miyasaka, 1966, p. 187). Kuni Nakajima writes that the greatly worsening economic situation after the Showa Financial Crisis deprived people of the means necessary to implement the life reform movement's recommendations, especially relating to the improved quality of life (Nakajima, 1974, p. 78). Yoshihiro Kobayashi writes that the movement, which primarily targeted the new urban middle class, reached its limits during the Taisho period when the size of that class was reduced (Kobayashi, 1984, pp. 327-328). Furthermore, Shizuko Koyama writes that since the life reform movement was especially active in Tokyo, it was greatly affected by the chaos that ensued after the Great Kantō Earthquake of 1923 (Koyama, 1999, p. 112).

Others have written that the stagnation of the life reform movement was caused by discrepancies between the target group imagined by the movement and the lifestyle models they proposed. Kuni Nakajima writes that, although the life reform movement claimed to be aimed at the urban middle class, it was also criticized at the time for being "a pastime for the wealthy upper class" (Nakajima, 1974, p. 77). Jordan Sand writes that the middle-class life imagined by the leaders of the life reform movement in the Taisho period was in fact the life of the relatively wealthy bourgeoisie, while the real middle class in that period was relatively new and had less disposable income (Sand, 2003, pp. 186-187). Furthermore, Kiyoshi Nakagawa writes that the lifestyle models suggested by the life reform movement were far from the average living standard of the new urban middle class and required a much higher standard of living (Nakagawa, 2011, pp. 80-83). If we organize the points made by Nakajima, Sand, and Nakagawa while taking into account the changes happening to the social structure at that time, we arrive at the following. The Meiji-period slogan of the "simple life" was aimed at the middle class, but it actually targeted the wealthy elite as well as the upper echelon of the new urban middle class. However, due to the subsequent rapid expansion of the new middle class, the majority had a relatively low level of income by the Taisho period (Tanuma \& Noda, 1957, pp. 31-32), all of whom were referred to as the middle class. Even so, the ideal middle-class lifestyle models imagined by the leaders of the Taisho-period movement remained premised on a high standard of living only attainable by a minority of people in the late Meiji period. It was the rigidity of the lifestyle models idealized by the leaders of the life reform movement that caused the discrepancy between its principles and the rapidly changing social structure.

\subsection{Aim of this Study}

Now, faced with this problem, did the leaders of the life reform movement change the objectives of their social education project?

In fact, those involved in the life reform movement did attempt to direct the movement toward a new demographic to address the movement's stagnation in the second half of the 1920s. The major change here was not an expansion of the scope of the middle-class, but rather a reorientation of the life reform movement toward farmers, who made up more than half of the country's population. This change can be said to have been a 
process by which the principle of life reform, which had been advocated in relation to only a small sector of Japanese society, was transformed into a principle that broadly encompassed the general population.

In the years after the war, the Japanese life reform movement (also known as the "new life movement (新生活運 動 Shin-seikatsu undō)" in the postwar period) was influenced by the democratization policies of the occupation forces as it took the form of dynamic activities principally targeting not the urban middle class, but the farmers who composed the majority of the population. As such, the life reform movement's prewar and postwar histories have been framed as non-continuous. However, I believe that a detailed understanding of the tendencies of the life reform movement after the second half of the 1920s can help to clarify which aspects were continuous between the prewar and postwar movements.

Until now, the fact that prewar life reform movement organizations established in the cities had an interest in other groups than the urban middle class has been given only fragmented treatment in the examination of the histories of those organizations (Nakajima, 1974, p. 83; Sand, 2003, p. 185; Isono, 2010, pp. 29-30). Research on how this change occurred and what it signified has been neither empirical nor sufficient.

Taking the above into account, the aim of the present study is thus as follows. This study seeks to clarify the background against which the leaders of the life reform movement after the second half of the 1920s suggested a new target demographic to replace the urban middle class, as well as how they sought to change their social education project based on that new target demographic.

\section{Method}

The subject of this study’s analysis is the Seikatsu Kaizen Dōmeikai (生活改善同盟会, The Life Reform League), an organization central to the Japanese life reform movement after the 1920s. The Life Reform League, founded in January 1920 with government funding, was originally a voluntary association, but became an incorporated foundation in October 1922. It was renamed Seikatsu Kaizen Chūōkai (生活改善中央会, The Central Association of Life Reform) in November 1933, and continued its work until 1943.

It is worthwhile examining the Life Reform League because it was involved in the life reform movement for a relatively long duration, spanning the Taisho and early Showa periods, and because it was a fairly large-scale organization. There were other prewar life reform organizations, such as the Household Association, the Housework Reform Association, and the Culture Diffusion Association, but most of these were involved in active social education projects relating to life reform only in the 1920s, discontinuing their work after 2-3 years. Since the investigation in this case study requires a long-term view of tendencies in the life reform movement, this organization is an ideal choice.

This study analyzes the assumptions that the Life Reform League (Central Association) made about its primary target demographic for life reform as well as how and why those assumptions came to change. The main source material used for this analysis consists of bulletin issues, monographs, and booklets published by the organization as well as its internal documents (e.g., meeting minutes and members lists).

\section{Results and Discussion}

\subsection{The Founding of the Life Reform League}

The direct impetus for the popularization of the word "life reform" in Japan was the Life Reform Exhibition organized by the Ministry of Education and the activities of the Life Reform League, which was founded during that exhibition.

In June 1919, Section 4 (later the Social Education Section) of the Bureau of Common Educational Affairs was established within the Ministry of Education as the government body responsible for social education. From the start, it engaged in the life reform movement through exhibitions and seminars, forming part of its principal social education project. One initiative that gained public attention was the Life Reform Exhibition held at the Tokyo Education Museum from November 1919 to February 1920. This exhibition had many display items related to food, clothing, housing, social life, domestic work, etc. Seminars, lectures, and activity photo screenings were also held in parallel with the exhibition. Moreover, most of the exhibits were lent to regional cities like Nagoya, Osaka, and Okayama after the end of the exhibition (Ehata, 1921, pp. 149-162).

Concurrent with this exhibition, the Life Reform League was founded in Tokyo in January 1920 under the leadership of Kaju Norisugi (乗杉嘉壽) (Director of Section 4 of the Bureau of Common Educational Affairs) and Gentarō Tanahashi (棚橋源太郎) (Director of the Tokyo Education Museum), and with the backing of the Ministry of Education and the Ministry of Home Affairs. At the time, the government and especially the Ministry of Education viewed the life reform movement as one of the principal projects of social education. 
Norisugi intended to promote the life reform movement over an extended duration, but fiscal restrictions necessitated private support and financial assistance for project execution. It was for this reason that he hurried to establish an organization in which not only bureaucrats, but also famous persons involved in women's education and organizations could participate in large numbers (Norisugi, 1921, p. 3).

Soon after the founding of the League, a variety of investigative committees were set up to examine and suggest what should be reformed in each area of life. Committees such as the "Housing Reform Investigative Committee," the "Clothing Reform Investigative Committee," the "Social Life Reform Investigative Committee," and the "Food Reform Investigative Committee" were established consecutively within the League. Resulting from these committees' work was the publication of booklets detailing what required reform in each area of life, such as Seikatsu kaizen chōsa kettei jikō (生活改善調査決定事項, Decisions from Investigations on Life Reform) (1921) and, Seikatsu Kaizen no shiori (生活改善の琹, Guidebook on Life Reform) (1924). Aside from these booklets, the League also started publishing the bulletin Seikatsu Kaizen (生活改善, Life Reform) in April 1921 to inform its members of its activity objectives and trends (Note 2).

In addition to the above, the Life Reform League organized many seminars, lectures, exhibitions, and the annual “Toki no Kinembi (時の記念日, Day of Time)” (Note 3) as well as dispatched lecturers to external events and lent out materials related to life reform.

A members list published in December 1920 gives the total membership of the Life Reform League as 2132 persons, of whom 1120 or more than half were Tokyo residents (Seikatsu Kaizen Domeikai, 1920). There is no extant record of how the membership developed after this period, but we can gather that it was an organization whose activities were centered in the cities (and especially Tokyo), at least around the time of its founding.

\subsection{The Life Reform League and the Middle Class}

The Life Reform League initially emphasized a life reform movement aimed at the middle class. First, let us consider the example of an opening editorial in the first issue of the organization bulletin Seikatsu Kaizen (April 1921), written by Jirō Yamagata (山縣治郎), a trustee of the Life Reform League. There, he hints at whom the life reform movement should be aimed by using the words "intelligentsia" (in Japan at the time, this was often used to refer to the new middle class) and "middle class (society)."

If I were to identify who is charged with the nation's advancement, despite perhaps being few in number, I would say that it is in fact the intelligentsia. The people below do not have the ability to deliberate on the nation together. Since it is the middle class that is actually and sincerely thinking about the progress of this civilization and the advancement of this nation, we have no choice but to rescue the wholesome middle-class society from this increasingly manifest situation [of poverty]. As such, I believe that this life reform can have a great effect even if it is just to rescue the middle class and no one else. (Yamagata, 1921, p. 12; author's italics, author's comments in square brackets)

The Life Reform League emphasized the middle class not only in its rhetoric, but also in the actual lifestyle models they proposed. The League set up multiple investigative committees in the first half of the 1920s, proposing a variety of lifestyle models. These numerous lifestyle models had in mind the new urban middle class, especially its upper echelons.

For example, Seikatsu kaizen chōsa kettei jikō (1921) describes "announcing death only to close relatives" and "brevity is valued in newspaper notices of funerals, so one ought not to carelessly list many names or submit several notices" as examples of proper social conduct (Seikatsu Kaizen Dōmeikai, 1921, p. 21). The organization also published Jutaku kagu no kaizen (住宅家具の改善, Reform of Housing and Furniture) in 1924, and each of the layout examples for "middle-class housing" presented there showed at least five rooms, including one for the maid (Seikatsu Kaizen Dōmeikai, 1924b, pp. 91-105). Considering the social norms and housing situation of that time, these proposals must have been premised on the average social and home life of the upper echelons of the new urban middle class or of the upper class (Nakagawa, 2011, pp. 83-88).

The articles in the League's bulletin Seikatsu Kaizen (Seikatsu) emphasized the transmission of practical knowledge about home life that assumed a readership in the new urban middle class. Special issues, such as "Handicraft Materials" (vol. 4, no. 8, 1928), "Entrance Study" (vol. 5, no. 1, 1929), "Laundry" (vol. 5, no. 5, 1929), and "Summer Clothes for Women and Children" (vol. 5, no. 8, 1929), were frequent, especially in the second half of the 1920s, and their contents indicated a shift in the target demographic, as the lifestyle models featured in many of the articles presumed a lower income than those proposed in the first half of the 1920s, reflecting the situation of the middle and lower reaches of the new urban middle class. 


\subsection{The Life Reform League and the Farmer Class}

As we have seen, a slight shift occurred in the target demographic of the Life Reform League throughout the 1920s. Nonetheless, a bigger change took place from the end of the 1920s through to the 1930s. During this period, voices within the Life Reform League were pointing out that its activities were prone to stagnation. The background of this stagnation has been already described in section 1.2. To overcome this stagnation, the League's leaders began doubting the erstwhile policy of focusing on the urban middle class and called for an expansion of the scope of the target population.

For example, Kingo Homori (甫守謹吾), a member of one of the League's investigative committees, wrote in the bulletin to point out that their activities had not been acknowledged by society at large and to argue that they should promote life reform without being biased to any one "class."

In order for the Japanese people to stand on the world stage and live without having to feel inferior in the least, the whole population must work together as one with firm resolve, advancing bravely toward [life reform]. Furthermore, this goal cannot be achieved unless the government authorities devote themselves to reforming the life situation down to the lower classes. In this way, the holy Life Reform League will not be fully effective unless it causes a [movement] that mobilizes the whole population (Homori, 1929, pp. 8-9; author's italics, author's comments in square brackets).

Moreover, the Life Reform League published Seikatsu kaizen jitsuwashū (生活改善実話集, The Collection of Testimonies on Life Reform), a book introducing several model cases of life reform in practice, in 1929. Eight of eleven cases introduced in this book praised the "hard work and frugality" of agricultural workers (Seikatsu Kaizen Domeikai, 1929). The farm village was emphasized as the site of life reform in practice and "farm village values," such as diligence and steadiness, were treated as the guiding principles of life reform.

By the 1930s, the leaders of the Life Reform League were seeking to change the movement's policy in more substantial ways. At a round-table talk organized by the Life Reform League in 1933, then League director Gentarō Tanahashi referenced the life reform movement's stagnation and the lack of awareness regarding how to promote a popular movement, upon which he argued that they should especially and actively promote a life reform movement aimed at farmers rather than urban residents, as demonstrated by the following:

Life reform [at present] is life reform for the cities, and not the kind of life reform that the whole of Japan is really looking for. (Seikatsu Kaizen Dōmeikai, 1933a, p. 22; author's comments in square brackets)

At the same round-table talk, it was argued that the life reform movement should be conducted in the farm villages where there was "true living," unlike in the cities. Shū Miyata (宮田脩, League director, principal of Seijo Higher Girls' School) made the following remarks on this subject:

It is said that Japan is facing a national crisis today, but I have given up on the crisis of urban residents. Urban residents are largely living fake lives. Very little of it is true. [...] In farm villages, however, I think relatively true living has been established or is being established. Yet I've recently heard that also the farm villages are gradually becoming impoverished and are facing extreme exhaustion and I'm afraid Japan will be completely destroyed if even the farm villages turn out like this." (Seikatsu Kaizen Dōmeikai, 1933a, p. 37)

In this way, the then leaders of the League had come to think in terms of a contrast between "cities" and "farm villages" when considering policies for overcoming the movement's stagnation.

\subsection{Organizational Reform in the Life Reform League}

The change in the target demographic of the League's activities also influenced the organizational reforms of the 1930s. Criticism of the current state of the League became even more explicit at the First All-Japan Life Reform Conference (hereinafter, the All-Japan Conference) in March 1933. This meeting gathered representatives of organizations and agencies working in the life reform movement all over Japan to debate and exchange information. A major topic of this First All-Japan Conference was strategies for extending the life reform movement to the local level. Another important issue that came to the fore at this meeting was that the League in Tokyo was far from fulfilling its role as communications manager, despite the existence of organizations actually engaged in life reform all over Japan (Seikatsu Kaizen Dōmeikai, 1933b, p. 19). 
Regional members expressed the idea that the life reform movement should be strongly promoted by "extending the so-called life reform network to the whole country" and "establishing municipal chapters" of the League organization (Seikatsu Kaizen Dōmeikai, 1933b, p. 12, 49). The general gist of the regional members' opinions was that the League should shift toward taking a leading role in relation to the householders', women's, and youth groups in the farm villages that formed the base of the small-scale life reform movement.

Following this debate at the All-Japan Conference, the League was reorganized into the Central Association of Life Reform in November 1933. The aim of this reorganization was for the Life Reform League to become a "central institution" that could "manage communications" between life reform organizations all over Japan (Seikatsu Kaizen Chūōkai, 1933, pp. 2-3).

Even after the reorganization into the Central Association, there were calls from within to expand the target demographic. The first item on the agenda for the Second All-Japan Conference in March 1934 was a debate about "what strategy is suitable for disseminating the ideas of life reform." At the beginning of that debate, one board member (unnamed) made the following remarks:

Especially until now, we have encouraged life reform to the intelligentsia, and the middle class, which are groups that have a relatively good understanding [of life reform], but in the future, we have to expect proper life reform also from somewhat lower classes and the working class. It can also be said that such people have extremely large potential when it comes to life reform (Seikatsu Kaizen Chūōkai, 1934, p. 18; author's italics, author's comments in square brackets).

Considering that the League's discussion of low-income classes had centered on farmers, it is likely that the reference to the "working class" signified farmers, rather than factory workers (Note 4). Here, it is obvious that the organization's erstwhile principle that presupposed the middle class as its target and subject had undergone a fundamental change. In addition to an expansion of the regional organizations decided on in the preceding year, the Second All-Japan Conference decided to establish a "regional life reform association" in each municipality, and a "life reform federation" in each prefecture and each of the six major cities (Tokyo, Yokohama, Nagoya, Osaka, Kyoto, and Kobe), to administer the regional life reform associations (Seikatsu Kaizen Chūōkai, 1934a, p. 32).

\section{5 "Small Groups" as the Movement's New Target}

Immediately following this reorganization, the organization bulletin featured an article encouraging members to establish independent, informal study groups in the form of "life reform groups." The proposed aim of these "life reform groups" was as follows:

We would like for these groups to be exceedingly free gatherings where, centering on especially ambitious members, everyone can talk about their study topics relating to life reform, investigate and discuss those issues, have round-table talks, organize reading circles, or sometimes even do practical work.

We would like for these groups to be voluntary organizations that do not depend on the communication channels between the Central Association and regional organizations, but may call on the Central Association or a regional organization when required.

Moreover, they are not groups wholly dedicated to serious study, but may well be informal groups. (Seikatsu Kaizen Chūōkai, 1934b, p. 48)

Furthermore, a "tentative standard" for the establishment and work of the life reform groups was given as follows (Seikatsu Kaizen Chūōkai, 1934b, p. 49):

1) Group membership should have an upper limit of about twenty people.

2) The group should gather at a member's home once or twice a month.

3) There should be no fixed fee, but everyone should contribute to cover the expenditures for each meeting.

4) The following are tasks that should be performed during meetings:

Tell each other about your own experiences of life reform.

Study on the basis of the bulletin Seikatsu.

Organize reading circles centering on literature that helps life reform.

Invite lecturers and have colloquia. 
Stimulate each other to reform your lives in practice.

Identify issues relating to life reform in the town or village where the group is located, investigate and study them, and encourage action.

Try to make sure that every meeting has an informal component.

Go observe relevant sites that can support life reform.

Submit the results of your meetings to the bulletin Seikatsu.

As indicated by the line "One town or village may have several groups" (Seikatsu Kaizen Chūōkai, 1934b, p. 49; author's italics) for this activity proposed by the Central Association, the intended target was not the cities, but rural areas. This proposal aimed at facilitating learning in small groups in rural areas with strong communal cohesion as a way to increase the independence of members' activities and thereby promote life reform.

As we have seen above, from the end of the 1920s to through the 1930s, the Life Reform League came to emphasize not the urban middle class, but farmers as the movement's principal participants. Moreover, they came to actively focus on not individual participation in the movement, but participation in small groups within traditional communities, so that people could belong to local organizations in their farm village or create their own small groups for studying life reform.

Even so, I must add that the Central Association of Life Reform's new activity policy was not necessarily realized properly. The plan to establish regional organizations ("regional committee members," "regional life reform associations") across Japan, including in the farming villages, was in fact never realized. Moreover, the efforts to encourage the formation of life reform groups also yielded few results. Behind these incomplete organizational reforms that were intended to promote the movement in the countryside figured the fragility of the League and the Central Association's financial base (Note 5).

Later, with the Second Sino-Japanese War and the Pacific War, it became increasingly difficult to continue the organization's activities. The Ministry of Education, which was the supervisory agency, approved the organization's application for dissolution in October 1943.

\section{Conclusion}

The life reform movement was originally born from Meiji-period ideas about simplifying and rationalizing the everyday life of the urban middle class. In this period, only the daily lives of a limited group of people were highlighted as the targets of reform. However, in the Showa period, the fact that the life reform movement was aimed at a narrow demographic came to be viewed as a source of the movement's stagnation, motivating calls for drastic change.

From the late 1920s through the 1930s, the leaders of the Life Reform League acknowledged the movement's stagnation and began exploring the option of targeting the farming class, who made up more than half of the population and possessed communal cohesion, rather than the difficult-to-mobilize urban middle class. Of course, it cannot be denied that the Central Association of Life Reform's attempt to expand the movement to rural areas was far from successful and that it ended as no more than slogans and plans, as we have seen. Nonetheless, the change in activity policy in the Life Reform League/Central Association of Life Reform in the 1930s can be said to be a clear indication of how the principle of life reform, originally concerned with only a part of Japanese society, transitioned to become a principle concerned with the entire population of Japan.

Postwar Japan saw economic revival as well as the reemergence of the life reform movement (the new life movement) (Gordon, 1997, pp. 251-259; Ōkado, 2012, pp. 2-4). In the postwar period, life reform was no longer seen as an exclusive possession of the middle class, but was something that was open to the whole population, with much attention initially being paid especially to initiatives aimed at farmers (Tanaka, 2011, pp. 17-25). The contribution of the present paper is the suggestion that this change did not happen suddenly due to the democratic reforms after the end of the war, but that it had already been happening gradually during the interwar period. In the 1920s and the 1930s, the task of reforming everyday "life" in Japanese society had ceased to be the task of a specific social class, and had changed to be one that was relevant to the majority of the people, at least in principle.

\section{Acknowledgement}

This study was supported by JSPS KAKENHI Grant Numbers JP16K04550. 


\section{References}

Ehata, K. (1921). Shakai kyōiku no jissaiteki kenkyū. Tokyo, Japan: Hakushinkan.

Garon, S. (1994). Rethinking modernization and modernity in Japanese history: A focus on state-society relations. The Journal of Asian Studies, 53(2), 346-366.

Gordon, A. (1997). Managing the Japanese household: The new life movement in postwar Japan. Social Politics: International Studies in Gender, State \& Society, 4(2), 245-283.

Hirade, Y. (2006). Kokka no seikatsu kaizen no torikumi: Seikatsu kaizen dōmeikai setsuritsu made. Seikatsu Bunka Shi, 49, 65-76.

Homori, K. (1929). Seikatsu kaizen no tettei o kisu. Seikatsu, 5 (12), 8-10.

Isono, S. (2010). Risō to genjitsu no aida ni: Seikatsu kaizen dōmeikai no katsudo. Tokyo, Japan: Shōwa Joshi Daigaku Kindai Bunka Kenkūsho.

Kobayashi, Y. (1984). Taishōki ni okeru shakai kyōiku seisaku no shintenkai: Seikatsu kaizen undō o chūshin ni. In Kōza Nihon Kyōikush Henshū Iinkai (Ed.), Kōza nihon kyōikushi dai 3 kan: Kindai II/Kindai III (pp. 308-331). Tokyo, Japan: Dai-Ichi Hōki.

Koyama, S. (1999). Katei no seisei to josei no kokuminka. Tokyo, Japan: Keisō Shobō.

Miyasaka, K. (1966). Kindai nihon shakai kyōiku seisakushi. Tokyo, Japan: Kokudosha.

Nakagawa, K. (2011). Seikatsu kaizen gensetsu no tokuchō to sono hen'yō: Seikatsu kaizen dōmeikai no kaizen jikō o chūshin ni. Shakai Kagaku, 42(1), 75-98.

Nakajima, K. (1974). Taishōki ni okeru "Seikatsu kaizen undo.” Shisō, 15, 54-83.

Norisugi, K. (1921). Seikatsu kaizen no igi. In Futsū Gakumukyoku (Bureau of Common Educational Affairs) (Ed.), Shakai kyōiku kōenshū kan (pp. 1-16). Tokyo, Japan: Mombushō (Ministry of Education).

Ōkado, M. (2012). Mondai no shozai to honsho no shiten, kadai. In M. Ōkado (Ed.), Shin-seikatsu undo to nihon no sengo: Haisen kara 1970 nendai (pp. 1-30). Tokyo, Japan: Nihon Keizai Hyōron-sha.

Sand, J. (2003). House and home in modern Japan: Architecture, domestic space and bourgeois culture, 1880-1930. Cambridge, MA: Harvard University Asia Center.

Shakai kyōikukyoku (Bureau of Social Education). (1940). Seijin kyōikuka shokan shisetsu gaiyō. Tokyo, Japan: Mombushō.

Seikatsu Kaizen Chūōkai (Central Association of Life Reform) (1933). Seimeisho. Seikatsu, 9(11), 2-3.

Seikatsu Kaizen Chūōkai (1934a). Dai nikai zenkoku seikatsu kaizen kankeisha kyōgi taikai giji kiroku. Seikatsu, 10(4), 10-47.

Seikatsu Kaizen Chūōkai (1934b). Honkai soshiki no kōshin ni kanshite. Seikatsu, 10(4), 48-49.

Seikatsu Kaizen Dōmeikai (Life Reform League) (1920). Seikatsu kaizen dōmeikai kaiin shimeiroku. Tokyo, Japan: Seikatsu Kaizen Dōmeikai.

Seikatsu Kaizen Dōmeikai (1921). Seikatsu kaizen chōsa kettei jikō. Tokyo, Japan: Seikatsu Kaizen Dōmeikai.

Seikatsu Kaizen Dōmeikai (1924a). Jūtaku kagu no kaizen. Tokyo, Japan: Seikatsu Kaizen Dōmeikai.

Seikatsu Kaizen Dōmeikai (1924b). Seikatsu kaizen no shiori. Tokyo, Japan: Seikatsu Kaizen Dōmeikai.

Seikatsu Kaizen Dōmeikai (1929). Seikatsu kaizen jitsuwashū. Tokyo, Japan: Seikatsu Kaizen Dōmeikai.

Seikatsu Kaizen Dōmeikai (1933a). Seikatsu kaizen no seishin yori mitaru jiriki kōsei zadankai. Seikatsu, 9(1), $16-45$.

Seikatsu Kaizen Dōmeikai (1933b). Kyōgikai no ki. Seikatsu, 10(5), 6-89.

Tanaka, S. (2011). Seikatsu kaizen shokatzudō ni tsuite. In S. Tanaka (Ed.), Kurashi no kakumei: Sengo nōson no seikatsu kaizen jigyō to shin-seikatsu undō (pp. 11-27). Tokyo, Japan: Nōsangyoson Bunka Kyōkai.

Tanuma, H., \& Masaho, N. (1957). Sararii-man no rekishi. In Y. Matsunari et al. (Eds.), Nihon no Sararii-man (pp. 31-37). Tokyo, Japan: Aoki Shoten.

Yamagata, J. (1921). Ōshū o kansatsushi masumasu waga kokumin seikatsu kaizen no kyū o omou. Seikatsu Kaizen, 1, 2-13. 


\section{Notes}

Note 1. The term "social education," used in Japan from the 1880s until the present, refers to adult education or, more broadly, to non-formal education.

Note 2. This bulletin used the revised title of Seikatsu (生活, Life) from 1925 to 1935. It was published until June 1943. Moreover, it was simply numbered by issue until 1924, but was subsequently numbered by both volume and issue.

Note 3. These were campaign activities held on June $10^{\text {th }}$ of every year that required people to behave by keeping time accurately in daily life.

Note 4. I have found 139 articles in the League and Central Association's bulletin on the subject of farmers published between 1921 and 1943. However, only 18 of these articles were on the subjects of the working class and the urban lower class.

Note 5. The Central Association of Life Reform received considerably little monetary assistance from the government compared to other social education organizations. For example, the Great Japan Young Men's Association, the Central Federation for Educational Organizations, and the Great Japan Federation of Young Women's Associations each received an annual 100,000 yen, 36,000 yen, and 10,000 yen, respectively, from the Ministry of Education, while the Central Association received 800 yen annually. The Central Association depended on donations from businesses and industrialists to fund its activities, but even then, its budget scale was quite small compared to other social education organizations (Shakai kyōikukyoku, 1940, pp. 151-156).

\section{Copyrights}

Copyright for this article is retained by the author(s), with first publication rights granted to the journal.

This is an open-access article distributed under the terms and conditions of the Creative Commons Attribution license (http://creativecommons.org/licenses/by/4.0/). 